\title{
Performance Analysis of 6063 Aluminium Alloy Semi-Circular Two Phase Closed Thermosyphon Tpct using $\mathrm{Fe}_{3} \mathrm{O}_{4}$ and Graphene Nano-Fluid $\triangleq$
}

\author{
D. Arokiya Pushparaj, N. Karunakaran, N. Alagappan
}

\begin{abstract}
Nanofluids stability on rest is important to characterize the nanofluids thermophysical properties before being used on different thermal systems. However, this stability can be modified during devices operation because of different thermal loads, fluid movements and phase changes. Particularly, in Two Phase Closed-Thermosyphon (TPCT). Input response are heat input, flow rate and inclination angle. Graphene and fe304 nanofluids used as working fluid in the fill ratio of $50 \%$. An attempt is made to optimise the process parameters with Response Surface Methodology (RSM) using Box - Behnken design for 6063 aluminium alloy (AA) semi-circular two phase closed thermosyphon (TPCT). Experiments are conducted by varying the mass flow rates of water at condenser section and by varying the heat input at evaporator section and varying inclination angle. The effects of variables on the process parameters are studied. The study, predominantly, aims at assessing how the variables affect the process parameters.
\end{abstract}

\section{INTRODUCTION}

Development of new technologies is hampered by heat management, exchange and evacuation for numerous fields of application. Nanofluids are a relatively recent class of fluids that have the potential to drastically increase heat exchange in energy systems compared to conventional fluids. This is achieved through the dispersion of nano-sized particles with enhanced thermal properties and stably suspended in a liquid medium. Indeed, thermal conductivity of nanofluids prepared with various nanoparticles has been reported to be enhanced compared to base liquids (water, ethylene glycol, etc.) at very low concentration of nanoparticles. Carbon nanomaterials, such as carbon nanotubes (CNTs) or graphene, which combine lightness and high thermal conductivity are widely recognized as excellent candidates for the new generation of nanofluids [1]. Incorporation of Thermosyphon, generally, a device having passive nature, can dissipate the heat in engineering operations. The device has three parts, namely the evaporator, adiabatic and condenser; the adiabatic is found between evaporator and condenser; and the evaporator found below the condenser, allows the flow of condensate using the action of gravity. This is the chief mechanism employed in the functioning of thermosyphon. Different working fluids such as DI water, acetone, refrigerants etc., are used as working fluids.

Revised Manuscript Received on October, 2020

* Correspondence Author

D. Arokiya pushparaj*, Assistant professor, Department of mechanical engineering, Annamalai university, Annamalai nagar, India

dr. N. Karunakaran, professor, Department of mechanical engineering, Annamalai university, Annamalai nagar, India.

dr. N. Alagappan, Assistant professor, Department of mechanical engineering, Annamalai university, Annamalai nagar, India.

(c) The Authors. Published by Blue Eyes Intelligence Engineering and Sciences Publication (BEIESP). This is an open access article under the CC BY-NC-ND license (http://creativecommons.org/licenses/by-nc-nd/4.0/)
These fluids have lower thermal properties which lead to cause constraints in significant heat transfer. Therefore its necessary to increase the enchanced properties of the working fluid. Most of the studies, conducted, focus attention on cylindrical shaped geometry [2,3,4-13]. But, in the case of thermal control in space craft, cooling process in electronic applications, besides commercial thermal applications, it has been an established fact that the capacity for removing heat and adopting geometric process in several applications, is found in the heat pipes having flat shape [1417]. Asirvatham et.al., in their study of thermosyphon using graphene - acetone nano-fluid with a concentration of $0.05 \%, 0.07 \%$ and $0.09 \%$ by volume and between a heat load of 10 and $50 \mathrm{~W}$ observed a substantial reduction in thermal resistance of $70.3 \%$ for the maximum concentration of $0.09 \%$ by volume of graphene -acetone nano-fluid.[18] Not much work was found in the literature using semicircular 6063 AA TPCTusing graphene nano-fluid and $\mathrm{Fe}_{3} \mathrm{O}_{4}$ nano-fluid. The literature review highlights the point that the types of cross-section, working fluid and the power input determine the TPCT functioning ability. This happens because the TPCT has a complex structure of boiling process which impacts on the thermal resistance and the overall performance of the TPCT. This experiment attempts to find the range of thermal enhancement of $\mathrm{Fe}_{3} \mathrm{O}_{4}$ and the Graphene nanofluid in semi-cicular 6063 AA TPCT.

\section{MATERIALS AND METHODS}

In order to narrow down on the choice of material be used in this study, the chemical composition test is performed and it is presented in Table 1 . The chemical composition identifies the container material as having alloyed with magnesium and silicon in a high quantity by weight percentage (wt\%). Therefore the grade of the material chosen for the study is semi- circular 6063AA TPCT. Some of the important properties used for the study are listed in the Table 2.

Table 1. Chemical composition (wt\%) of Aluminium (6063 AA) as container metal

\begin{tabular}{llllllll}
\hline $\mathbf{M g}$ & $\mathbf{S i}$ & $\mathbf{F e}$ & $\mathbf{C u}$ & $\mathbf{M n}$ & $\mathbf{Z n}$ & $\mathbf{C r}$ & $\mathbf{A l}$ \\
\hline 0.7 & 0.532 & 0.35 & 0.1 & 0.7 & 0.02 & 0.1 & Remainder \\
\hline
\end{tabular}

Table 2. Key properties of 6063 AA

\begin{tabular}{ll}
\hline Density & $2.7 \mathrm{~g} / \mathrm{cm}^{3}$ \\
\hline Thermal conductivity K & $200 \mathrm{~W} / \mathrm{mK}$
\end{tabular}

Thermal expansion coefficient $23 \mathrm{~m} / \mathrm{m}^{\circ} \mathrm{C}$ 


\section{Performance Analysis of 6063 Aluminium Alloy Semi-Circular Two Phase Closed Thermosyphon Tpct using $\mathrm{Fe}_{3} \mathrm{O}_{4}$ and Graphene Nano-Fluid}

III. EXPERIMENTAL SET UP

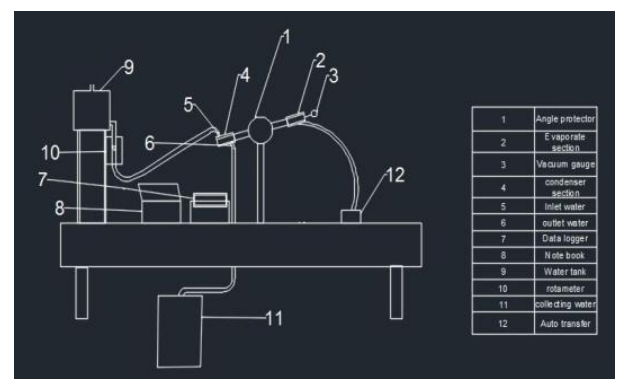

Fig 1. Layout of experimental setup

Using semi-circular 6063 AA TPCT and a set of working fluids having different nature, the two phase closed Thermosyphon (TPCT) analysis to determine the thermal performance is engaged as shown in figure 1.The setup consists of the following equipment and facilities.

Semi-circular 6063AA TPCTs are used for this experimental study. The inclinometer (Bevel Protector) provision is made on the test rig to rotate the TPCT through $0^{\circ}$ - $180^{\circ}$ angle.

In order to provide heat input the evaporator section is wrapped with 200 watts capacity and the power supply is monitored with three phase variact which can regulate the power supply necessary for the experiment. The variac employed, here, is capable of holding 1800 watts with 230 volts and 20 amps. The power supply provided to the heater of the evaporator section is maintained by a wattmeter and the 3 phase variac holds a range of $0-250$ watts and 230 volts. The load administered is found on the wattmeter digital display. The TPCT gets soldered, along its entire length, with the K-type thermocouples at eight different locations, which are connected with a logger system to obtain accurate results on temperature measurement. Water passing through the condenser jacket is the appropriate mode of measuring the power output of TPCT.

A design of 6063 AA TPCT and 6063 AA jacket having $30 \mathrm{~mm}$ outer diameter and $250 \mathrm{~mm}$ length with the provision of inlet and outlet and positioned, diagonally, opposite to each other, to facilitate swirl flow to proposed. Similarly, the semi-circular $6063 \mathrm{Al}$ Alloy TPCT jacket is also fabricated with the same material and the rotometer is attached to monitor the flow rate of coolant water discharged from the water tank.

The evaporator section of the TPCT is connected with a heat source of plate type heater with a maximum power output of $200 \mathrm{~W}$ at $220 \mathrm{~V}$. The condenser section is cooled by tap water. The mass flow rate of condenser section is controlled by rotometer. The adiabatic section is insulated by glass wool to avoid heat energy interaction with the ambience. Before charging the working fluid, the TPCT enclosure is evacuated and maintained at a vacuum of $99 \mathrm{kPa}$ to $100 \mathrm{kPa}$. Then the required amount of the working fluid is charged.

The container material was tested with a filling ratio of 50 percent. The wall temperature on the TPCT container materials is measured by eight thermocouples of K-type. Two thermocouples were mounted on the evaporator section, two on the adiabatic section and four on the condenser section. The location of thermocouples is shown in Fig 1. All the thermocouples (K-Type) are connected and monitored using 8channel data logger system. The flat plate type heater attached to the evaporator is connected to a variac having three phases with
20 amps capacity. The heat input is varied by using a variac. The heating power input can be observed from watt mater.

\section{Preparation of nanofluids}

In the present work, a two step method was employed to prepare the nanofluids. Graphene nano particles (30nm), purchased form USA, is well dispersed into DI water at a concentration of $0.09 \%$ by volume .The well dispersed sample is subjected to the sonication process in bath type ultrasonic homogenizer (Olee Pvt Ltd, $42 \mathrm{~K}_{\mathrm{Hz}}$ ) up to 12 hours it is shown in fig 2. Similarly $\mathrm{Fe}_{3} \mathrm{O}_{4}$ nano-fluid prepared in the concentration of $0.09 \%$ by volume and sonicated for 15 hours it is shown in fig 3 .

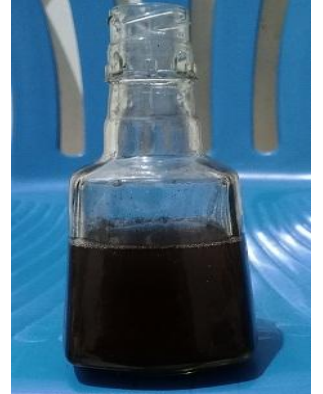

1. Graphene nanofluid

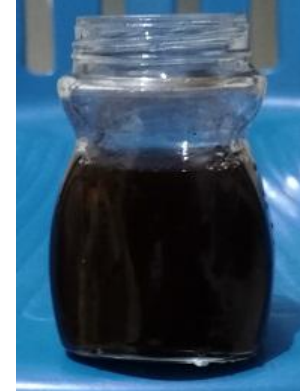

2. $\mathrm{Fe}_{3} \mathrm{O}_{4}$ nano fluid

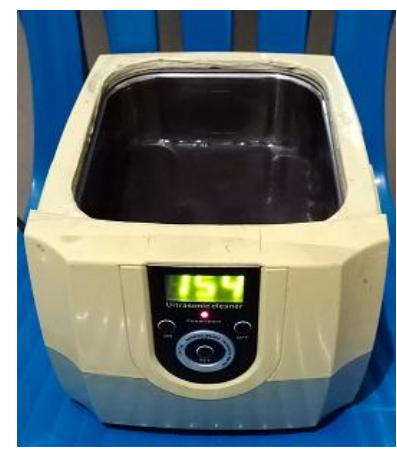

3. Ultrasonic Homogenizer

It is necessary to adopt potential type of procedure, in the design of experiments and to analyse the data collected. In order to optimize the input parameters for the desired performance, the RSM is employed for the Design of Experiments. Box - Behnken type has three different parameters such as heat input (A), angle inclination(B) and flow rate of water(C) which help us obtain the responses thermal resistance $\left(\mathrm{R}_{\mathrm{th}}\right)$ and the heat transfer coefficient $\left(\mathrm{U}_{\text {overall }}\right)$.

Table 3. Indicates the process parameters with their levels

\begin{tabular}{|c|c|c|c|}
\hline \multirow{2}{*}{ Parameters } & \multicolumn{3}{|c|}{ Level } \\
\cline { 2 - 4 } & $\mathbf{- 1}$ & $\mathbf{0}$ & $\mathbf{1}$ \\
\hline Heat Input, W & 60 & 80 & 100 \\
\hline Angle of inclination, ${ }^{\circ}$ & 30 & 60 & 90 \\
\hline Flow Rate, ml/min & 60 & 90 & 120 \\
\hline
\end{tabular}

Published By:
Blue Eyes Intelligence Engineering (C) Copyright: All rights reserved. and Sciences Publication

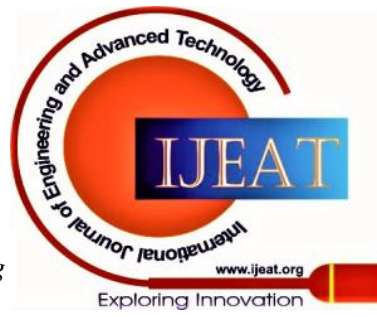

Exploing Innovation 
Table 4. Indicates the Design of Matrix

\begin{tabular}{|c|c|c|c|c|}
\hline Std & Run & $\begin{array}{c}\text { Factor 1 } \\
\text { A: Heat } \\
\text { Input }\end{array}$ & $\begin{array}{c}\text { Factor 2 } \\
\text { B: Angle of } \\
\text { Inclination }\end{array}$ & $\begin{array}{c}\text { Factor 3 } \\
\text { C: Flow } \\
\text { Rate }\end{array}$ \\
\hline $\mathbf{2}$ & 1 & 80 & 60 & 90 \\
\hline $\mathbf{1}$ & 2 & 80 & 90 & 120 \\
\hline $\mathbf{7}$ & 3 & 60 & 90 & 90 \\
\hline $\mathbf{5}$ & 4 & 100 & 60 & 120 \\
\hline $\mathbf{1 6}$ & 5 & 100 & 90 & 90 \\
\hline $\mathbf{9}$ & 6 & 100 & 30 & 90 \\
\hline $\mathbf{1 0}$ & 7 & 80 & 60 & 90 \\
\hline $\mathbf{4}$ & 8 & 60 & 60 & 60 \\
\hline $\mathbf{1 4}$ & 9 & 80 & 30 & 60 \\
\hline $\mathbf{1 3}$ & 10 & 80 & 30 & 120 \\
\hline $\mathbf{8}$ & 11 & 80 & 60 & 90 \\
\hline $\mathbf{1 1}$ & 12 & 60 & 30 & 90 \\
\hline $\mathbf{1 2}$ & 13 & 60 & 60 & 120 \\
\hline $\mathbf{1 7}$ & 14 & 80 & 60 & 90 \\
\hline $\mathbf{3}$ & 15 & 100 & 60 & 60 \\
\hline $\mathbf{1 5}$ & 16 & 80 & 60 & 90 \\
\hline $\mathbf{6}$ & 17 & 80 & 90 & 60 \\
\hline $\mathbf{T}$ & 4 & & 60 & \\
\hline
\end{tabular}

Table 4 gives the results for BBD, based on the three factors, and the simulation arranged for 17 runs in their order. The 17 runs are conducted as per the resulting design matrix by varying, the mass flow rate of pure water flowing through the condenser section using rotometer, the inclination angle of TCPT and heat input. Approximately it took 15 minutes for graphene nano-fluid and $20 \mathrm{~min}$ for $\mathrm{Fe}_{3} \mathrm{O}_{4}$ nano-fluid to attain the steady state. The data logger system is used to record the temperature, during each trail, after arriving at the steady state.

\section{A. Data reduction}

Data reduction is a process which transforms the numerical and alphabetical information available in digital form, which have been evolved empirically and experimentally into a correct, orderly and simple pattern. The principle behind this reduction is condensation of large number of data into easily accessible and relevant segments.

The following formula is used to evaluate the thermosyphon's thermal efficiency:

$$
\begin{aligned}
& \eta \%=\frac{Q_{\text {out }}}{Q_{\text {in }}} \\
& Q_{\text {out }}=\dot{m}_{c} \cdot c_{p} \cdot\left(T_{\text {out }}-T_{\text {in }}\right)
\end{aligned}
$$

where,

$m_{c}=$ Mass flow rate of pure water in condenser section, $\mathrm{kg} / \mathrm{sec}$.

$\mathrm{C}_{\mathrm{p}}=$ Specific heat of water, $\mathrm{J} / \mathrm{kg}^{\circ} \mathrm{C}$
$\mathrm{T}_{\text {out }}=$ Temperature at outlet of the water condenser section, ${ }^{\circ} \mathrm{C}$

$\mathrm{T}_{\text {in }}=$ Temperature at inlet of the water condenser section ${ }^{\circ} \mathrm{C}$

$\mathrm{Q}_{\text {in }}=$ Heat input in watts

Uncertainty for $\eta \%$ is evaluated by,

$$
\begin{gathered}
e=\frac{\partial \eta}{\eta}=\left[\sum_{t-1}^{N}\left(\frac{1}{\eta} \times \frac{\partial R}{\partial x i} \partial x i\right)^{2}\right]^{1 / 2} \\
=\left[\left(\frac{\partial m}{m}\right)^{2}+\left(\frac{\partial Q_{\text {out }}}{Q_{\text {out }}}\right)^{2}+\left(\frac{\partial Q_{\text {in }}}{Q_{\text {in }}}\right)^{2}\right]^{1 / 2}
\end{gathered}
$$

By calculating $\eta_{1}$ for the entire experimental range, the maximum uncertainty is associated with the resulting of $\eta_{\%}$ values that found to be around 1.42 percent.

\section{RESULTS AND DISCUSSION}

\begin{tabular}{|c|c|c|c|c|c|c|}
\hline Source & $\begin{array}{l}\text { Sum of } \\
\text { Squares }\end{array}$ & df & $\begin{array}{l}\text { Mean } \\
\text { Square }\end{array}$ & $\begin{array}{c}F \\
\text { Value }\end{array}$ & $\begin{array}{c}\text { p-value } \\
\text { Prob }>\text { F }\end{array}$ & \\
\hline Model & 0.14 & 9 & 0.016 & 54.56 & $\begin{array}{c}< \\
0.0001\end{array}$ & $\begin{array}{c}\text { signifi } \\
\text { cant }\end{array}$ \\
\hline $\begin{array}{c}\text { A- } \\
\text { HEAT } \\
\text { INPUT }\end{array}$ & 0.016 & 1 & 0.016 & 57.27 & 0.0001 & \\
\hline $\begin{array}{c}\text { B- } \\
\text { ANGL } \\
\text { E }\end{array}$ & $\begin{array}{c}6.037 \mathrm{E} \\
-003\end{array}$ & 1 & $\begin{array}{l}6.037 \\
\text { E-003 }\end{array}$ & 21.02 & 0.0025 & \\
\hline $\begin{array}{c}\text { C- } \\
\text { FLOW } \\
\text { RATE }\end{array}$ & 0.040 & 1 & 0.040 & $\begin{array}{c}140.6 \\
8\end{array}$ & $\begin{array}{c}< \\
0.0001\end{array}$ & \\
\hline $\mathrm{AB}$ & $\begin{array}{c}4.381 \mathrm{E} \\
-004\end{array}$ & 1 & $\begin{array}{l}4.381 \\
\text { E-004 }\end{array}$ & 1.52 & 0.2567 & \\
\hline $\mathrm{AC}$ & $\begin{array}{c}1.947 \mathrm{E} \\
-004\end{array}$ & 1 & $\begin{array}{l}1.947 \\
\text { E-004 }\end{array}$ & 0.68 & 0.4375 & \\
\hline $\mathrm{BC}$ & $\begin{array}{c}6.845 \mathrm{E} \\
-004\end{array}$ & 1 & $\begin{array}{l}6.845 \\
\text { E-004 }\end{array}$ & 2.38 & 0.1666 & \\
\hline$A^{2}$ & 0.014 & 1 & 0.014 & 47.83 & 0.0002 & \\
\hline $\mathrm{B}^{2}$ & $\begin{array}{c}4.266 \mathrm{E} \\
-003\end{array}$ & 1 & $\begin{array}{l}4.266 \\
\text { E-003 }\end{array}$ & 14.85 & 0.0063 & \\
\hline$C^{2}$ & 0.053 & 1 & 0.053 & $\begin{array}{c}184.0 \\
7\end{array}$ & $\begin{array}{c}< \\
0.0001\end{array}$ & \\
\hline $\begin{array}{c}\text { Residu } \\
\text { al }\end{array}$ & $\begin{array}{c}2.011 \mathrm{E} \\
-003\end{array}$ & 7 & $\begin{array}{l}2.873 \\
\text { E-004 }\end{array}$ & & & \\
\hline $\begin{array}{l}\text { Lack } \\
\text { of Fit }\end{array}$ & $\begin{array}{c}2.011 \mathrm{E} \\
-003\end{array}$ & 3 & $\begin{array}{l}6.703 \\
\text { E-004 }\end{array}$ & & & \\
\hline $\begin{array}{l}\text { Pure } \\
\text { Error }\end{array}$ & 0.000 & 4 & 0.000 & & & \\
\hline $\begin{array}{c}\text { Cor } \\
\text { Total }\end{array}$ & 0.14 & $\begin{array}{l}1 \\
6\end{array}$ & & & & \\
\hline
\end{tabular}

Response 1 EFFICIENCY - $\mathrm{Fe}_{3} \mathrm{O}_{4}$ Nano-fluid ANOVA for Response Surface Quadratic ModelAnalysis of variance table [Partial sum of squares - Type III]

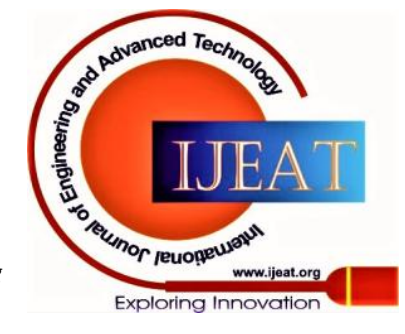




\section{Performance Analysis of 6063 Aluminium Alloy Semi-Circular Two Phase Closed Thermosyphon Tpct using $\mathrm{Fe}_{3} \mathrm{O}_{4}$ and Graphene Nano-Fluid}

The Model F-value of 54.56 indicates the model as important. The model F value of such a magnitude can occur rarely with $0.01 \%$ of chance because of noise.this large

$-0.010$

$+6.977 \mathrm{E}-003$

$-0.013$

$-0.057$

$-0.032$

$-0.11$

$$
\begin{array}{r}
* \mathrm{~A} * \mathrm{~B} \\
* \mathrm{~A} * \mathrm{C} \\
* \mathrm{~B} * \mathrm{C} \\
* \mathrm{~A}^{2} \\
* \mathrm{~B}^{2} \\
* \mathrm{C}^{2}
\end{array}
$$

The Pred R-Squared value of 0.7751 is in reasonable

\begin{tabular}{|c|c|c|c|c|c|c|}
\hline Factor & $\begin{array}{l}\text { Coefficie } \\
\text { nt } \\
\text { Estimate }\end{array}$ & $\begin{array}{l}\text { d } \\
\text { f }\end{array}$ & $\begin{array}{c}\text { Standar } \\
\text { d } \\
\text { Error }\end{array}$ & $\begin{array}{c}95 \\
\% \\
\text { CI } \\
\text { Low }\end{array}$ & $\begin{array}{c}95 \% \\
\text { CI } \\
\text { High }\end{array}$ & $\begin{array}{l}\text { VI } \\
\text { F }\end{array}$ \\
\hline $\begin{array}{c}\text { Interce } \\
\mathrm{pt}\end{array}$ & 0.71 & 1 & $\begin{array}{c}\text { 7.580E- } \\
003\end{array}$ & 0.69 & 0.72 & \\
\hline $\begin{array}{c}\text { A- } \\
\text { HEAT } \\
\text { INPUT }\end{array}$ & 0.045 & 1 & $\begin{array}{c}5.992 \mathrm{E}- \\
003\end{array}$ & $\begin{array}{c}0.03 \\
1\end{array}$ & 0.060 & $\begin{array}{c}1.0 \\
0\end{array}$ \\
\hline $\begin{array}{c}\text { B- } \\
\text { ANGL } \\
\text { E }\end{array}$ & 0.027 & 1 & $\begin{array}{c}\text { 5.992E- } \\
003\end{array}$ & $\begin{array}{c}0.01 \\
3\end{array}$ & 0.042 & $\begin{array}{c}1.0 \\
0\end{array}$ \\
\hline $\begin{array}{c}\text { C- } \\
\text { FLOW } \\
\text { RATE }\end{array}$ & 0.071 & 1 & $\begin{array}{c}\text { 5.992E- } \\
003\end{array}$ & $\begin{array}{c}0.05 \\
7\end{array}$ & 0.085 & $\begin{array}{c}1.0 \\
0\end{array}$ \\
\hline$A B$ & -0.010 & 1 & $\begin{array}{c}8.474 \mathrm{E}- \\
003\end{array}$ & $\begin{array}{c}- \\
0.03 \\
1\end{array}$ & $\begin{array}{l}9.574 \\
\text { E-003 }\end{array}$ & $\begin{array}{c}1.0 \\
0\end{array}$ \\
\hline $\mathrm{AC}$ & $\begin{array}{c}\text { 6.977E- } \\
003\end{array}$ & 1 & $\begin{array}{c}8.474 \mathrm{E}- \\
003\end{array}$ & $\begin{array}{c}- \\
0.01 \\
3\end{array}$ & 0.027 & $\begin{array}{c}1.0 \\
0\end{array}$ \\
\hline BC & -0.013 & 1 & $\begin{array}{c}8.474 \mathrm{E}- \\
003\end{array}$ & $\begin{array}{c}- \\
0.03 \\
3\end{array}$ & $\begin{array}{l}6.958 \\
\text { E-003 }\end{array}$ & $\begin{array}{c}1.0 \\
0\end{array}$ \\
\hline$A^{2}$ & -0.057 & 1 & $\begin{array}{c}8.260 \mathrm{E}- \\
003\end{array}$ & $\begin{array}{c}- \\
0.07 \\
7\end{array}$ & -0.038 & $\begin{array}{c}1.0 \\
1\end{array}$ \\
\hline $\mathrm{B}^{2}$ & -0.032 & 1 & $\begin{array}{c}8.260 \mathrm{E}- \\
003\end{array}$ & $\begin{array}{c}- \\
0.05 \\
1\end{array}$ & -0.012 & $\begin{array}{c}1.0 \\
1\end{array}$ \\
\hline$C^{2}$ & -0.11 & 1 & $\begin{array}{c}8.260 \mathrm{E}- \\
003\end{array}$ & - & -0.093 & $\begin{array}{c}1.0 \\
1\end{array}$ \\
\hline
\end{tabular}
agreement with the Adj R-Squared value of 0.9679 .

"Adeq Precision" measures the signal to noise ratio. A ratio greater than 4 is desirable. Your ratio of 21.435 indicates an adequate signal. This model can be used to navigate the design space.

Final Equation in Terms of Coded Factors:

$\begin{array}{ll}\text { EFFICIENCY } & = \\ +0.71 & \\ +0.045 & * \mathrm{~A} \\ +0.027 & * \mathrm{~B} \\ +0.071 & * \mathrm{C}\end{array}$

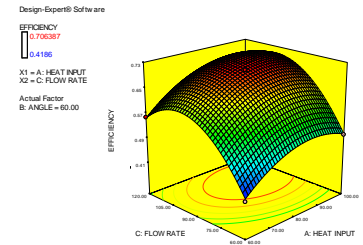

Fig 4: Effect of $\mathrm{FE}_{3} \mathrm{O}_{4} \mathrm{Nano}$

Fig 5. Effect of FE3O4 Nano fluid regarding heat input and flow rate

Fig 6. Effect of $\mathrm{FE}_{3} \mathrm{O}_{4}$ Nano fluid regarding flow rate and angle

Thermal efficiency is found to increase gradually with increase in heat input and angle. Integrated effect of inclination angle and flow rate maximum thermal efficiency is achieved. Whereas the combinatorial effect of heat input and flow rate shows the high value of thermal efficiency. On account of the heat flux increase, caused by the increase of temperature gradient occurring between evaporator and condenser, there is an increase in the thermal efficiency of heat pipe(Amit Faghri 2016).The heat input shows higher values as more heat is generated in the surface and the working fluid, found in state of vapour, enters rapidly into the condenser section.

The performance of the TPCT increases when the excess heat is obsorbed by the circulating water in the condenser section. Hence, the influential input parameters among are the heat input at evaporator inclination angle Richter and Gottschlich, (1994) and flow rate. However, 
the semi-circular cross section carries the heat and transport in a proper way from evaporator section to condenser section with minimum heat loss. This occurs since the surface temperature, in the evaporation section, is found higher than the vapour temperature, the heat gets transferred to vapour core as the evaporator maintains direct contact with the electrical heater. The advantage of using semi circular cross section helps in returning the working fluid quickly to the evaporator section from the condenser section after give up the heat. This phenomenon eventually maximizes the efficiency.

Response 1 EFFICIENCY - graphene nano-fluid ANOVA for Response Surface Quadratic Model Analysis of variance table [Partial sum of squares - Type III]

\begin{tabular}{|c|c|c|c|c|c|c|}
\hline Source & $\begin{array}{c}\text { Sum } \\
\text { of } \\
\text { Squar } \\
\text { es }\end{array}$ & $\begin{array}{l}\text { d } \\
\text { f }\end{array}$ & $\begin{array}{c}\text { Mean } \\
\text { Squar } \\
\text { e }\end{array}$ & $\begin{array}{c}\text { F } \\
\text { Valu } \\
\mathbf{e}\end{array}$ & $\begin{array}{c}\text { p- } \\
\text { value } \\
\text { Prob } \\
>\text { F }\end{array}$ & \\
\hline Model & 0.33 & 9 & 0.036 & $\begin{array}{c}127.7 \\
3\end{array}$ & $\begin{array}{c}< \\
0.000 \\
1 \\
\end{array}$ & $\begin{array}{c}\text { significa } \\
\text { nt }\end{array}$ \\
\hline $\begin{array}{c}\text { A- } \\
\text { HEAT } \\
\text { INPUT }\end{array}$ & $\begin{array}{c}2.196 \mathrm{E} \\
-003\end{array}$ & 1 & $\begin{array}{l}2.196 \\
\text { E-003 }\end{array}$ & 7.75 & $\begin{array}{c}0.027 \\
1\end{array}$ & \\
\hline $\begin{array}{c}\text { B- } \\
\text { ANGL } \\
\text { E }\end{array}$ & $\begin{array}{c}5.476 \mathrm{E} \\
-005\end{array}$ & 1 & $\begin{array}{l}5.476 \\
\text { E-005 }\end{array}$ & 0.19 & $\begin{array}{c}0.673 \\
5\end{array}$ & \\
\hline $\begin{array}{c}\text { C- } \\
\text { FLOW } \\
\text { RATE }\end{array}$ & 0.23 & 1 & 0.23 & $\begin{array}{c}808.1 \\
3\end{array}$ & $\begin{array}{c}< \\
0.000 \\
1 \\
\end{array}$ & \\
\hline $\mathrm{AB}$ & 0.013 & 1 & 0.013 & 46.77 & $\begin{array}{c}0.000 \\
2\end{array}$ & \\
\hline AC & $\begin{array}{c}1.947 \mathrm{E} \\
-004\end{array}$ & 1 & $\begin{array}{l}1.947 \\
\text { E-004 }\end{array}$ & 0.69 & $\begin{array}{c}0.434 \\
5\end{array}$ & \\
\hline BC & 0.011 & 1 & 0.011 & 38.65 & $\begin{array}{c}0.000 \\
4\end{array}$ & \\
\hline$A^{2}$ & 0.011 & 1 & 0.011 & 39.34 & $\begin{array}{c}0.000 \\
4\end{array}$ & \\
\hline$B^{2}$ & 0.027 & 1 & 0.027 & 93.59 & $\begin{array}{c}< \\
0.000 \\
1\end{array}$ & \\
\hline$C^{2}$ & 0.025 & 1 & 0.025 & 89.52 & $\begin{array}{c}< \\
0.000 \\
1\end{array}$ & \\
\hline $\begin{array}{c}\text { Residu } \\
\text { al }\end{array}$ & $\begin{array}{c}1.983 \mathrm{E} \\
-003\end{array}$ & 7 & $\begin{array}{l}2.834 \\
\text { E-004 }\end{array}$ & & & \\
\hline $\begin{array}{c}\text { Lack } \\
\text { of Fit }\end{array}$ & $\begin{array}{c}1.983 \mathrm{E} \\
-003 \\
\end{array}$ & 3 & $\begin{array}{c}6.612 \\
\text { E-004 } \\
\end{array}$ & & & \\
\hline $\begin{array}{l}\text { Pure } \\
\text { Error }\end{array}$ & 0.000 & 4 & 0.000 & & & \\
\hline $\begin{array}{c}\text { Cor } \\
\text { Total }\end{array}$ & 0.33 & $\begin{array}{l}1 \\
6 \\
\end{array}$ & & & & \\
\hline
\end{tabular}

The Model F is considered significant as it records the value of 127.73 and the model $F$ value of this magnitude could occur with $0.01 \%$ chance.

When the model has the value of less than 0.0500 for "prob $>F$ ", it is considered as significant. indicate model terms are significant.

Here the $\mathrm{A}, \mathrm{C}, \mathrm{AB}, \mathrm{BC}, \mathrm{A}^{2}, \mathrm{~B}^{2}$ and $\mathrm{C}^{2}$ are considered as they show the "prob $>F$ " values as greater than 0.1000 to as certain that the model terms as non significant. In the event of more number of insiginificant model terms occur, excepting those needed to maintain support hierarchy, the model reduction will improve the model.

Std. Dev. $0.017 \quad$ R-Squared 0.9939

Mean $\quad 0.69$ Adj R-Squared 0.9862

$\begin{array}{lll}\text { C.V. \% } & 2.45 \quad \text { Pred R-Squared } & 0.9032\end{array}$

PRESS $0.032 \quad$ Adeq Precision 34.315

The "Pred R-Squared" of 0.9032 is in reasonable agreement with the "Adj R-Squared" of 0.9862 .

"Adeq Precision" measures the signal to noise ratio. A ratio greater than 4 is desirable.

Your ratio of 34.315 indicates an adequate signal. This model can be used to navigate the design space.

\begin{tabular}{|c|c|c|c|c|c|c|}
\hline Factor & $\begin{array}{l}\text { Coefficie } \\
\text { nt } \\
\text { Estimate }\end{array}$ & $\begin{array}{l}\text { d } \\
\text { f }\end{array}$ & $\begin{array}{c}\text { Standar } \\
\text { d } \\
\text { Error }\end{array}$ & $\begin{array}{c}95 \\
\% \\
\text { CI } \\
\text { Low }\end{array}$ & $\begin{array}{c}95 \% \\
\text { CI } \\
\text { High }\end{array}$ & $\begin{array}{l}\text { VI } \\
\text { F }\end{array}$ \\
\hline $\begin{array}{c}\text { Interce } \\
\mathrm{pt}\end{array}$ & 0.78 & 1 & $\begin{array}{c}\text { 7.528E- } \\
003\end{array}$ & 0.77 & 0.80 & \\
\hline $\begin{array}{c}\text { A- } \\
\text { HEAT } \\
\text { INPUT }\end{array}$ & -0.017 & 1 & $\begin{array}{c}\text { 5.951E- } \\
003\end{array}$ & $\begin{array}{c}- \\
0.03 \\
1\end{array}$ & $\begin{array}{c}- \\
2.497 \\
\text { E-003 }\end{array}$ & $\begin{array}{c}1.0 \\
0\end{array}$ \\
\hline $\begin{array}{c}\text { B- } \\
\text { ANGL } \\
\text { E }\end{array}$ & $\begin{array}{c}2.616 \mathrm{E}- \\
003\end{array}$ & 1 & $\begin{array}{c}\text { 5.951E- } \\
003\end{array}$ & $\begin{array}{c}- \\
0.01 \\
1\end{array}$ & 0.017 & $\begin{array}{c}1.0 \\
0\end{array}$ \\
\hline $\begin{array}{c}\text { C- } \\
\text { FLOW } \\
\text { RATE }\end{array}$ & 0.17 & 1 & $\begin{array}{c}\text { 5.951E- } \\
003\end{array}$ & 0.16 & 0.18 & $\begin{array}{c}1.0 \\
0\end{array}$ \\
\hline $\mathrm{AB}$ & 0.058 & 1 & $\begin{array}{c}\text { 8.417E- } \\
003\end{array}$ & $\begin{array}{c}0.03 \\
8\end{array}$ & 0.077 & $\begin{array}{c}1.0 \\
0\end{array}$ \\
\hline $\mathrm{AC}$ & $\begin{array}{c}\text { 6.977E- } \\
003\end{array}$ & 1 & $\begin{array}{c}8.417 \mathrm{E}- \\
003\end{array}$ & $\begin{array}{c}- \\
0.01 \\
3\end{array}$ & 0.027 & $\begin{array}{c}1.0 \\
0\end{array}$ \\
\hline BC & -0.052 & 1 & $\begin{array}{c}8.417 \mathrm{E}- \\
003\end{array}$ & $\begin{array}{c}- \\
0.07 \\
2\end{array}$ & -0.032 & $\begin{array}{c}1.0 \\
0\end{array}$ \\
\hline$A^{2}$ & -0.051 & 1 & $\begin{array}{c}\text { 8.203E- } \\
003\end{array}$ & $\begin{array}{c}- \\
0.07 \\
1\end{array}$ & -0.032 & $\begin{array}{c}1.0 \\
1\end{array}$ \\
\hline$B^{2}$ & -0.079 & 1 & $\begin{array}{c}\text { 8.203E- } \\
003\end{array}$ & $\begin{array}{c}- \\
0.09 \\
9\end{array}$ & -0.060 & $\begin{array}{c}1.0 \\
1\end{array}$ \\
\hline$C^{2}$ & -0.078 & 1 & $\begin{array}{c}\text { 8.203E- } \\
003\end{array}$ & $\begin{array}{c}- \\
0.09 \\
7\end{array}$ & -0.058 & $\begin{array}{c}1.0 \\
1\end{array}$ \\
\hline
\end{tabular}

Final Equation in Terms of Coded Factors: EFFICIENCY

$+0.78$

$-0.017$

$+2.616 \mathrm{E}-003$

$+0.17$

$+0.058$

$+6.977 \mathrm{E}-003$

$-0.052$

$-0.051$

$-0.079$

$-0.078$

Published By:

Blue Eyes Intelligence Engineering and Sciences Publication

(c) Copyright: All rights reserved.

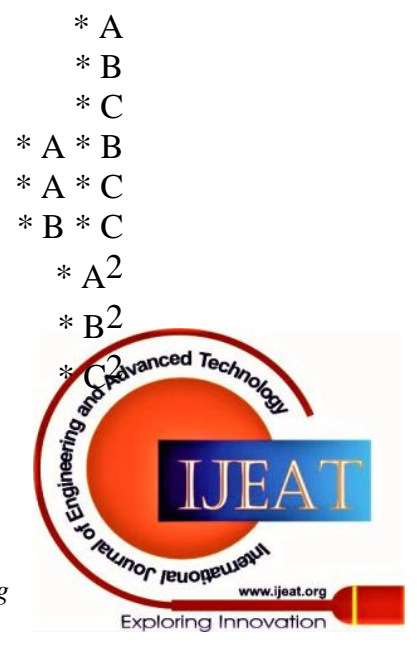




\section{Performance Analysis of 6063 Aluminium Alloy Semi-Circular Two Phase Closed Thermosyphon Tpct using $\mathrm{Fe}_{3} \mathrm{O}_{4}$ and Graphene Nano-Fluid}

Final Equation
EFFICIENCY
+0.012950
$+8.22665 \mathrm{E}-003$
+0.023721
$+9.59292 \mathrm{E}-005$
$+1.16278 \mathrm{E}-005$
-5.81389E-005
-1.28632E-004
-8.81773E-005
-8.62394E-005

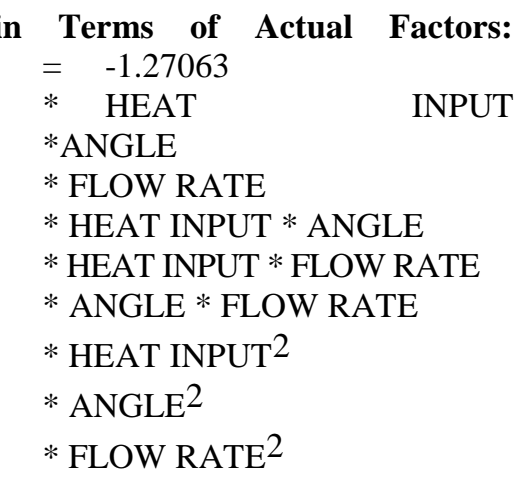

Fig 7: Effect of $\mathrm{FE}_{3} \mathrm{O}_{4}$ Nano fluid regarding heat input and angle
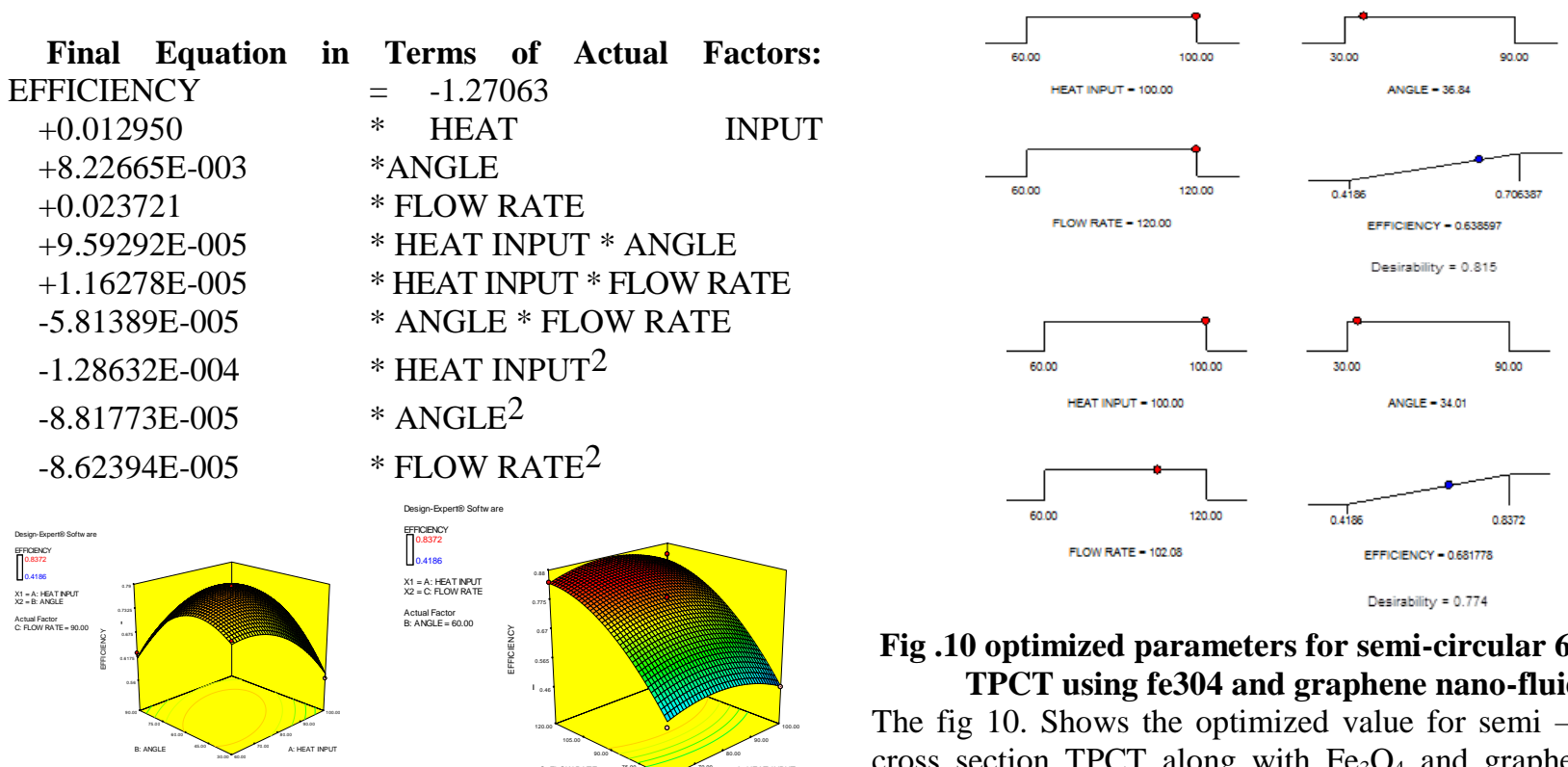

Desirability $=0.77$

Fig .10 optimized parameters for semi-circular 6063 AA TPCT using fe304 and graphene nano-fluid.

The fig 10. Shows the optimized value for semi - circular cross section TPCT along with $\mathrm{Fe}_{3} \mathrm{O}_{4}$ and graphene nano fluid . semi -circular TPCT with graphene nano-fluid the enhancement in thermal performance is $5 \%$ more when compare to $\mathrm{Fe}_{3} \mathrm{O}_{4}$ nano-fluid filled semi-circular tpct . this is because of higher wettability of graphene nano-fluid that enhances the efficiency .

\section{CONCLUSIONS}

It is aimed to investigate the performance of semi circular TPCT with $\mathrm{Fe}_{3} \mathrm{O}_{4}$ and graphene nano-fluids. Out of the present study the following conclusions have been made .

$>$ The semi-circular 6063 AA TPCT increases the number of nucleation site and enchances the boiling characteristics as it introduces a large number of nucleation bubbles which are small in size.

Fig 9: Effect of $\mathrm{FE}_{3} \mathrm{O}_{4}$ Nano fluid regarding flow rate and angle

The thermal efficiency of the heat pipe is calculated as the ratio of heat rejected at the condenser section to heat input at evaporator section(Naphon,2009). Fig7. shows the effect of heat input and inclination angle on thermal efficiency. The figure shows how the effect of heat input causes gradual decrease in the thermal efficiency, initially, and increase when there is increase in flow rate causing a steep increase in the efficiency of the thermal state. The interactive effect of flow rate and angle increases the thermal efficiency. The heat flux being the cause for the increased thermal efficiency of the heat pipe, there is an increase in the temperature gradient lies between the evaporator and condenser section. For higher values of heat input in evaporator section, the heat generated in the surface is more and graphene nano-fluid which is in form of vapor moves vigorously in to the condenser section. The circulating water, in the condenser section, absorbs the excessive heat and so the efficiency of TPCT increases. Hence, the influential input parameters are the heat input at evaporator inclination angle and flow rate. The thermal efficiency is maximum up to 60 ० inclination angle and then decreases. Since the viscosity of graphene nano fluid is more so it shows a Newtonian behaviour when compared to $\mathrm{Fe}_{3} \mathrm{O}_{4}$ nano-fluid. performance by $5 \%$ more when compared to $\mathrm{Fe}_{3} \mathrm{O}_{4}$ nano-fluid filled semi-circular TPCT. is found higher than the vapour evaporator maintain direct contact with the electrical heater, hence the heat is transferred to the vapour core area. The advantage of using semi-circular cross section returning the

working fluid quickly to the evaporator section from the condenser section after eliminating the heat. This phenomenon eventually increases efficiency.

\section{REFERENCES}

1. R. Saidur, K. Y. Leong, and H. A. Mohammad, A review on applications and challenges of nanofluids Renewable and Sustainable Energy Reviews 15, 1646 (2011)

2. Shafahi, M., Bianco, V., Vafai, K., and Manca, O. An Investigation of The Thermal Performance of Cylindrical Heat Pipes

using Nanofluids, Int. J. Heat Mass Transfer 53 (1-3) (2010) 376-383.

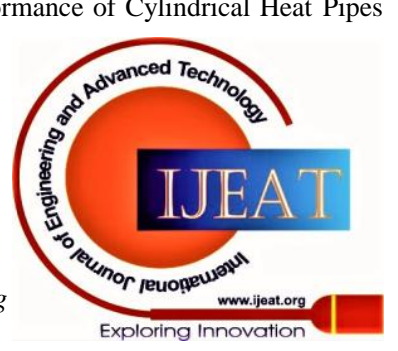


3. Zhu, N. and Vafai, K. Analysis of Cylindrical Heat Pipes Incorporating The Effects of Liquid-Vapor Coupling and NonDarcian Transport - A Closed Form Solution, Int. J. Heat Mass Transfer 42 (18) (1999) 3405-3418.

4. Kang, S. W., Wei, W. C. Tsai, S. H. and Yang, S. Y. Experimental Investigation of Silver Nano-Fluid on Heat Pipe Thermal Performance, Appl. Thermal Eng. 26 (17-18) (2006) 23772382.

5. Kang, S. W., Wei, W. C., and Tsai, C. C. Huang, Experimental Investigation of Nanofluids on Sintered Heat Pipe Thermal Performance, Appl. Thermal Eng. 29 (5-6) (2009) 973-979.

6. Lin, Y. H., Kang, S. W. and Chen, H. L. Effect of Silver Nano-Fluid on Pulsating Heat Pipe Thermal Performance, Appl. Therm. Eng. 28 (11-12) (2008) 1312-1317.

7. Ma, H. B. Wilson, C., Borgmeyer, B., Park, K., Yu, Q., Choi, S. U. S. and Tirumala, M. Effect of Nanofluid on The Heat Transport Capability in an Oscillating Heat Pipe, Appl. Phys. Lett. 88 (14) (2006) 143113-143116.

8. Ma, H. B., Wilson, C., Yu, Q., Park, K. and Choi, M. Tirumala, An Experimental Investigation of Heat Transport Capability in a Nanofluid Oscillating Heat Pipe, J. Heat Transfer 128 (11) (2006) 1213-1216.

9. Naphon, P. Assadamongkol, P. and Borirak, T, Experimental Investigation of Titanium Nanofluids on The Heat Pipe Thermal Efficiency, Int. Commun. Heat Mass 35 (10) (2008) 1316-1319.

10. Naphon, P., Thongkum, D. and Assadamongkol, P, Heat Pipe Efficiency Enhancement with Refrigerant-Nanoparticles Mixtures, Energy Convers. Manage. 50 (3) (2009) 772-776.

11. Tournier, J. M. and El-Genk, M. S, A Heat Pipe Transient Analysis Model, Int. J. Heat Mass Transfer 37 (5) (1994) 753-762.

12. Tsai, C. Y., Chien, H. T., Ding, P. P., Chan, B., Luh, T. Y. and Chen, P. H, Effect of Structural Character of Gold Nanoparticles in Nanofluid on Heat Pipe Thermal Performance, Mater. Lett. 58 (9) (2004) 1461-1465.

13. Shafahi, M., Bianco, V., Vafai, K. and Manca, O, Thermal Performance of Flat-Shaped Heat Pipes using Nanofluids, Int. J. Heat Mass Transfer 53 (7-8) (2010) 1438- 1445.

14. Vafai, K. and Wang, W, Analysis of Flow and Heat Transfer Characteristics (PDF) Performance of TiO 2 Nanofluid and DI Water Filled Flat Type Heat Pipe (FTHP) Internally Grooved at Various Fill Ratios and Inclinations. an Asymmetrical Flat Plate Heat Pipe, Int. J. Heat Mass Transfer 35 (9) (1992) 2087-2099.

15. Wang, Y. amd Vafai, K, Transient Characterization of Flat Plate Heat Pipes During Startup and Shutdown Operations, Int. J. Heat Mass Transfer 43 (15) (2000) 2641-2655.

16. Wang, Y. and Vafai. K, an Experimental Investigation of the Thermal Performance of an Asymmetrical Flat Plate Heat Pipe, Int. J. Heat Mass Transfer 43 (15) (2000) 2657-2668.

17. Wang, Y. and Vafai, $\mathrm{K}$, an Experimental Investigation of the Transient Characteristics on a Flat-Plate Heat Pipe During Startup and Shutdown Operations, J. Heat Transfer 122 (3) (2000) 525-535.

18. Lazarus Godson Asirvatham, Somchai Wongwises, Jithu Babu, Heat transfer performance of a glass thermosyphon using grapheneacetone nanofluid, Journal of Heat Transfer 137 (11), 2015.

\section{AUTHORS PROFILE:}

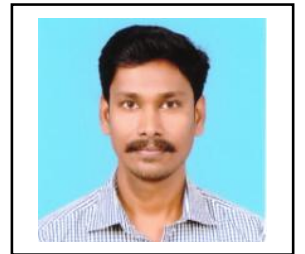

Mr.D.AROKIYA

PUSHPARAJ.

B.E.,M.E., obtained his Bachelor's Degree from Madras University and Master's Degree from Annamalai University. He is currently serving as Assistant Professor in the Department of Mechanical Engineering at Annamalai University, India. He has three publications in National and Internationa journals to his credit. He is also Member of Indian Society for Technical Education (MISTE).

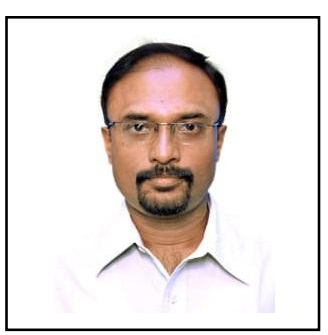

\section{Second Author:}

Dr. N. KARUNAKARAN., B.E., M.B.A. ,M.E.,Ph.D., is an Professor, Department of Mechanical Engineering, Annamalai University, India. He has publishes more than 22 research articles in peer reviewed board and has been reviewer in high impact factor Journals. Key positions Director - Annamalai Innovation Centre (From May 2018 onwards), Nodal
Officer - TNSURF Tamil Nadu State University Ranking Framework (2018), Nodal Officer - The QS Ranking - (2019), Nodal Officer - The ARIIA Ranking by MHRD - (2019), Nodal Officer - The Times Higher Education World University Ranking (THE) - (2018) (2019), Nodal Officer - Report preparation for MHRD-NIRF (2017) (2018) (2019), Deputy Director - In charge of Annamalai Innovation Centre (From May 2016 to May 2018), Deputed to Creative Promo Cell - AIC, Annamalai University. (From 2014 Onwards), Editorial Board Member - Annamalai University Newsletter. (From 2014 Onwards), Nodal Officer - Web updates for Annamalai Innovation centre. For Faculty of Engineering \& Technology And also member in Life Member, Indian Welding Society. Member in Energy \& Fuel User's Association of India. Editorial Board Member International Journal of Mechanical Engineering and Applications (IJMEA),Member - International Association of Engineers (IAENG).

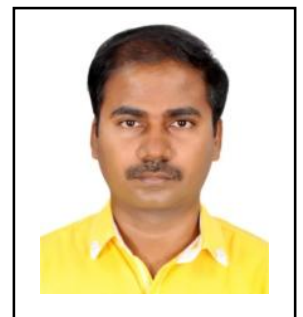

Third Author:

Dr.N. ALAGAPPAN.,Ph.D., is an Assistant Professor, at the Department of Mechanical Engineering, Annamalai University, India. He has published more than 16 research articles in peer reviewed journals and has been reviewer in taylor and francis also in Elsevier journals. $\mathrm{He}$ is also presented papers at various conferences in various countries. He is also senior member in International Association of Educators and Researcher(IAER) and member in International of Engineers.

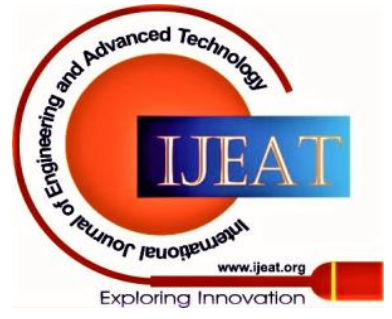

